\title{
Optimal Diversification, Bank Value Maximization, and Default Probability
}

\author{
Yung-Shun Tsai ${ }^{a}$, Chien-Chih Lin ${ }^{b *}$ and Hsiao-Yin Chen ${ }^{c}$ \\ ${ }^{\mathrm{a}}$ Department of Finance, Asia University, \\ No.500, Liufeng Rd., Wufeng Dist., Taichung City 413, Taiwan \\ ${ }^{b}$ Department of Banking and Finance, Tamkang University, \\ 151, Ying-Chuan Rd., Tamsui, Taipei County, 25137 Taiwan \\ ${ }^{c}$ Department of Business and Entrepreneurial Management, Kainan University, \\ No.1 Kainan Rd. Luzhu, Taoyuan Country 33857 Taiwan \\ *Corresponding Author:139714@mail.tku.edu.tw
}

\begin{abstract}
This study discusses the existence of the optimal diversification to maximize bank value. It finds that the impact of diversification on bank value depends on the business cycle. Since diversification can lower individual risk and raise system risk simultaneously, it will not always be beneficial for financial institutions to diversify their assets fully. This paper finds that, in a good economy, there will be an optimal diversification to maximize a bank's value, but in a bad economy, diversification will hurt a bank's value. Empirical evidence from Taiwan's banks is provided.
\end{abstract}

Keywords: Diversification; Business Cycle; Systemic Risk; Banking

\section{Introduction}

International financial transactions and investments contribute to diversifying the assets of financial institutions, especially banks. Diversification can reduce individual risk, but the shocks of the recent mortgage and financial crises in the US and the credit crises in Europe have resulted in financial institutions' having to withstand more risk because of their diversification. 
Of course, diversification has benefits. Elsas et al. (2010) examined the impact of diversification on bank value during 1996-2008 and found two reasons for diversification's ability to increase bank value. The first is banks' economies of scope: because of their frequently long-term relationships with customers, banks can get more client information than non-financial institutions can in order to improve diversification in products and services. In addition, banks' high operating leverage allows banks more opportunities to find low-cost capital sources and achieve economies of scope. The second reason that diversification can increase bank value is due to the technological advantage and liberalization of the financial industries, such as progress in financial marketing technologies (e.g., the foot-in-the-door strategy of requesting small demands before major ones) and the spread of financial openness and liberalization, including financial derivatives and financial consolidation, to financially developing countries. Enterprise integration also provides internal capital markets to improve efficiency in the allocation of funds (e.g., Williamson, 1975; Stein, 1997). The cost of the internal capital market is usually lower than that of the external capital market (Goold and Luchs, 1993; Ghemawat, 2000), so it can reduce cost and increase profit while also reducing information asymmetry. Hadlock et al. (2001) showed that external financing in the open market had more serious adverse selection problems than did financing in internal markets. Khanna and Palepu (1999) studied the role of diversification in India's enterprises and found that diversification can create shareholder value via products and labor and that diversification has a risk transfer effect in financial markets, particularly in emerging markets that are not fully developed. Lewellen (1971) argued that enterprise integration could improve capital efficiency and increase debt capacity, thereby improving corporate value by means of debt expansion.

Chandler (1977) and Teece (1982) confirmed that economies of scope can improve the efficiency of resource allocation, reduce costs, and increase corporate value, while Bhide (1990) suggested that diversified investment could address consumer, supplier, borrower, and tax issues to increase the efficiency of resource use. Montgomery (1994) proposed three major theoretical viewpoints - the agency theory, the resource-based view, and market power-to explain why enterprises may choose to diversify investments. According to the agency theory, the manager may seek diversified investment in order to (1) increase his or her compensation (Jensen and Murphy, 1990), power, and reputation (Jensen, 1986); (2) consolidate his or her position in the company by using expertise in investment (Shleifer and Vishny, 1990; Shleifer and Vishny, 1991); and/or (3) reduce the risk in his or her personal investment portfolio by lowering corporate risk (Amihud and Lev, 1981). From the resource-based view, when a company has excessive capital for investment, activities 
that take advantage of economies of scope, such as the integration of marketing channels and operating strongholds after product diversification, can increase corporate efficiency (Penrose, 1959). Moreover, the integration of legal and financial resources can be improved by using diversified business operations (Wernerfelt and Montgomery, 1988; Bodnar et al., 1999). Using the perspective of the market power theory, Villalonga (2000) proposed three reasons why enterprises choose investment diversification to increase market power: (1) to use a company's profits to offset the price-cutting competition of another; (2) to ally with other companies to compete with rivals in multiple markets; and (3) to crowd out smaller firms by investing in major enterprises to expand market share.

On the other hand, diversification has its costs. Wagner (2010) argued that portfolio diversification increases opportunities for asset overlap. Under the influence of the wealth effect, a bank failure would decrease the wealth of another bank that holds the same assets, leading to further collapse and the possibility of systematic crisis. Goldstein and Pauzner (2004) suggested that, under the influence of wealth effect, international portfolio diversification would trigger international "risk infection" since bad news in one country would reduce investors' wealth, resulting in rising risk aversion and disinclination to invest in other countries. Allen and Carletti (2006) and Allen and Gale (2005) argued that the credit risk transfer effect between the insurance and banking industries would lead to risk transfer from the insurance industry to the banking industry. When the banking and the insurance industry hold the same assets, the insurance industry may lower prices in order to sell the assets in times of crisis, harming the banking industry that holds the same assets. If the loss expands to a certain level, bank failures can result.

Diversification may also result in increasing agency problems and increasing corporate costs (e.g., Jensen, 1986; Meyer et al., 1992), and inefficient resource allocation may arise from the functional failure of internal capital markets (e.g., Lamont, 1997; Scharfstein and Stein, 2000a; Rajan et al., 2000). In addition, information asymmetry between investment companies and managers of the companies in which they invest (e.g., Harris et al., 1992) is detrimental to business operations since information asymmetry may increase the rent-seeking behaviors of the managers and enable them to engage in non-productive profit-seeking activities (e.g., Scharfstein and Stein, 2000b), increasing corporate costs and lowering corporate value.

Despite the competing positive and negative effects of diversification, studies on optimal diversification are rare. This study attempts to determine the conditions necessary for an optimal level of diversification to exist using the banking industry as an example. The study follows the model Wagner (2010) used to explore the effect of 
diversification in reducing individual risk and increasing system risk. We find that optimal diversification is related to the business cycle: When the economy is good, there is an optimal diversification level for maximizing banks' value, and when the economy is bad, diversification will lower bank value.

Other literature has focused on why banks undertake diversification. For example, Acharya (2001) and Acharya and Yorulmazer (2005) indicated that banks hold affiliated assets because they do not consider the system risk cost. Acharya and Yorulmazer $(2007 ; 2008)$ argued that banks expect the possibility of simultaneous crises to increase, so the authorities have to save them in time of crisis. There have been no empirical studies on optimal diversification.

This study uses Taiwan's banks to conduct empirical tests of optimal diversification. Our findings suggest that an optimal level of diversification does exist in Taiwan's banking samples, possibly because of the boom conditions of Taiwan's banking industry.

The remainder of this paper is organized as follows. Section 2 presents the theoretical model, which uses the business cycle to determine the optimal diversification to maximize banks' value. Using Taiwan's banking industry as an example, Section 3 tests the impact of diversification on the banks' value. Section 4 offers conclusions, integrates the theoretical and empirical results, and proposes suggestions for future studies.

\section{The Model}

Wagner (2010) pointed out that diversification affects corporations in two ways: by reducing individual corporate risk in order to enhance corporate value and by increasing system risk to lower corporate value. Therefore, full diversification is not necessarily the best solution. This paper attempts to determine the conditions necessary for an optimal level of diversification to exist.

To derive the optimal degree of diversification in the banking system we follow the framework used in Wagner (2010). Consider a three-period economy and two banks. Suppose each bank has collected one unit of funds from investors, of which a share $d$ is in the form of deposits and the remaining share is capital. At time 1 bank 1 invests in an asset $X$, and bank 2 invests in an asset $Y$. Each asset requires one unit of funds. The values of the assets are independent and uniformly distributed on the interval $[0, s]$; that is

$$
f_{X}(x)=f_{Y}(y)=\frac{1}{s}, \forall x, y \in[0, s],
$$

where $f_{X}(x)$ and $f_{Y}(y)$ are the probability density functions of the values of assets 
$X$ and $Y$. At time 2, each bank decides whether to transfer its asset to the other bank. We denote $r_{i} \in\left[0, \frac{1}{2}\right], i \in\{1,2\}$, the share of a bank invests in a new asset. Thus, the bank is undiversified if $r_{i}=0$, and fully diversified if $r_{i}=1 / 2$. The payoffs of assets are realized at time 3 , and the values of banks 1 and 2 at time 3 are

$$
\begin{aligned}
& v_{1}\left(x, y ; r_{1}\right)=\left(1-r_{1}\right) x+r_{1} y \\
& v_{2}\left(x, y ; r_{2}\right)=r_{2} x+\left(1-r_{2}\right) y
\end{aligned}
$$

When the value of bank 1 is less than $d$, it is insolvent, and it has to liquidate its assets. If the other bank is solvent, then the failing bank can sell its assets to the other bank for their total value, reduced by $c$; that is $v_{i}(x, y)-c$. If the other bank is insolvent as well, then the assets of bank 1 have to be acquired by outsiders who are inferior users of the assets, so the assets have to be liquidated at a loss of $q c$, where $q \geq 1$. Under these assumptions, the expected value for banks 1 and 2, $W_{1}$ and $W_{2}$, can be written as

$$
\begin{aligned}
& W_{1}\left(r_{1}, r_{2}\right)=E\left[v_{1}\left(r_{1}\right)\right]-c P\left(v_{1}\left(r_{1}\right) \leq d, v_{2}\left(r_{2}\right)>d\right)-q c P\left(v_{1}\left(r_{1}\right) \leq d, v_{2}\left(r_{2}\right) \leq d\right) \\
& W_{2}\left(r_{1}, r_{2}\right)=E\left[v_{2}\left(r_{2}\right)\right]-c P\left(v_{2}\left(r_{2}\right) \leq d, v_{1}\left(r_{1}\right)>d\right)-q c P\left(v_{1}\left(r_{1}\right) \leq d, v_{2}\left(r_{2}\right) \leq d\right)
\end{aligned}
$$

Therefore, the total welfare in the economy is the sum of the expected values of bank 1 and 2:

$$
\begin{aligned}
W_{1}\left(r_{1}, r_{2}\right)+W_{2}\left(r_{1}, r_{2}\right) & =E\left[v_{1}\left(r_{1}\right)\right]+E\left[v_{2}\left(r_{2}\right)\right] \\
& -c\left(P\left(v_{1}\left(r_{1}\right) \leq d, v_{2}\left(r_{2}\right)>d\right)+P\left(v_{2}\left(r_{2}\right) \leq d, v_{1}\left(r_{1}\right)>d\right)\right) \\
& -2 q c P\left(v_{1}\left(r_{1}\right) \leq d, v_{2}\left(r_{2}\right) \leq d\right) .
\end{aligned}
$$

Since $E\left[v_{i}\left(r_{i}\right)\right]$ is independent of $r_{i}$, the optimal diversification simply minimizes the total expected liquidation losses at both banks. Because of symmetry, the optimal degrees of diversification for banks 1 and 2 are equal. Therefore, we can focus on the losses for bank 1 and solve

$$
\operatorname{Min}_{\mathrm{r}} c\left(P\left(v_{1}(r) \leq d, v_{2}(r)>d\right)+q P\left(v_{1}(r) \leq d, v_{2}(r) \leq d\right)\right)
$$

Using these assumptions, the optimal degree of diversification can be derived.

Proposition 1. The optimal degree of diversification in the banking system is given by $r^{*}=\frac{1}{1+\sqrt{2 q-1}}$ when $\frac{d}{s} \leq \frac{1}{1+\sqrt{2 q-1}}$, and $r^{*}=0$ when $\frac{d}{s}>\frac{1}{1+\sqrt{2 q-1}}$.

Proof. See Appendix A.

Unlike Wagner (2010), who showed that the optimal degree of diversification is $\frac{1}{1+\sqrt{2 q-1}}$, we find that the optimal degree diversification depends on the probability 
of liquidation $\left(\frac{d}{s}\right)$. When the probability of liquidation is less than or equal to $\frac{1}{1+\sqrt{2 q-1}}$, the optimal degree of diversification is consistent with that of Wagner (2010). However, when the probability of liquidation is more than $\frac{1}{1+\sqrt{2 q-1}}$, the optimal degree of diversification is 0 .

In the Nash equilibrium, the degree of diversification for Bank 1 is solved by

$$
\operatorname{Max}_{\mathrm{r}_{1}} E\left[v_{1}\left(r_{1}\right)\right]-c P\left(v_{1}\left(r_{1}\right) \leq d, v_{2}\left(r_{2}\right)>d\right)-q c P\left(v_{1}\left(r_{1}\right) \leq d, v_{2}\left(r_{2}\right) \leq d\right),
$$

which leads to Proposition 2:

Proposition 2. In the Nash equilibrium the degree of diversification in the banking sector is given by $r^{E}=\frac{1}{1+\sqrt{q}}$ when $\frac{d}{s} \leq \frac{1}{1+\sqrt{q}}$, and $r^{E}=0$ when $\frac{d}{s}>\frac{1}{1+\sqrt{q}}$.

Proof. See Appendix B.

Unlike Wagner (2010), who showed that the equilibrium degree of diversification is $\frac{1}{1+\sqrt{q}}$, we find that the equilibrium degree diversification depends on the probability of liquidation $\left(\frac{d}{s}\right)$. When the probability of liquidation is less than or equal to $\frac{1}{1+\sqrt{q}}$, the optimal degree of diversification is consistent with Wagner (2010). However, when the probability of liquidation is more than $\frac{1}{1+\sqrt{q}}$, the optimal degree of diversification is 0 .

Since $\left(\frac{d}{s}\right)$ is the probability of liquidation, it is reasonable to assume that the value of $\left(\frac{d}{s}\right)$ depends on the business cycle. When the economy is good (bad) and opportunities for profitable investments increase (decrease), the highest possible value of bank assets increases (decreases) and $\left(\frac{d}{s}\right)$ falls (rises).

The threshold of optimal diversification is related to the cost of liquidation by outsiders $q$. In this study, the threshold of the optimal diversification is $\frac{1}{1+\sqrt{2 q-1}}$ 
in general equilibrium and $\frac{1}{1+\sqrt{q}}$ in the Nash equilibrium. The cost of liquidation by outsiders $q$ is suggested to be constant in the short term, which implies that the threshold would also be constant in the short term. The implications of our results are as follows:

\section{a. An optimal diversification is more likely to exist in a good economy than in a bad economy.}

When the economy is good, the highest value of the bank assets $s$ is higher than when the economy is bad; hence, the probability of liquidation $\left(\frac{d}{s}\right)$ is likely to be less than the threshold, and there is an optimal level of diversification to maximize banks' value is more likely to exist.

\section{b. In case a bad economy, more diversification lowers bank value.}

When the economy is bad, the highest value of the bank's assets $s$ is lower, so the probability of liquidation $\left(\frac{d}{s}\right)$ is likely to be higher than the threshold and to lead to a lower bank value when there is more diversification.

\section{Empirical Results}

Using Taiwan's banking industry as an example, this section tests whether an optimal level of diversification can exist and, if it does, under what conditions. Because the financial systems of emerging markets are not mature and changes in financial structure are dramatic, the banking industry's cyclic fluctuations are apparent. Since the demands for funds from banks are relatively high, the fluctuations in the banking industry could easily have an overall impact. In addition, the market value of listed banks in Taiwan accounts for a relatively large percentage of the total market, and the high level of financial integration includes banking; hence, diversification is an important subject for Taiwan's banking industry and worth examination.

\subsection{Sample}

We chose 33 publicly listed banks in Taiwan from TEJ (Taiwan Economic Journal) data bank as the screening group, based on the length of their history and the availability of data. We excluded banks that were merged into financial holding companies because of difficult access to data and their reduced business independence. 
Then we selected banks from this group whose business cycle was apparent (equity market capitalization had once been lower than book value, namely, Tobin's q value was $<1$ ) and whose levels of diversification had fluctuated. After this screening, we were left with ten publicly listed banks and 120 monthly observations for each year from 2000 to 2009. Table 1 lists descriptive statistics for the corporate value indicator (Tobin Q) and the diversification indicator (Herfindal H) in our sample.

Table 1 Descriptive Statistics

\begin{tabular}{|c|c|c|c|c|c|c|c|c|c|c|}
\hline Bank & Tobir & & & & & H & & & & \\
\hline & Mean & Median & Max & Min & S.D. & Mean & Median & Max & Min & S.D. \\
\hline 2801 & 1.004 & 1.006 & 1.040 & 0.968 & 0.015 & 0.337 & 0.372 & 0.613 & 0.090 & 0.139 \\
\hline 2809 & 0.987 & 0.987 & 1.032 & 0.952 & 0.020 & 0.244 & 0.222 & 0.625 & 0.046 & 0.148 \\
\hline 2812 & 0.984 & 0.986 & 1.022 & 0.945 & 0.021 & 0.274 & 0.230 & 0.666 & 0.100 & 0.144 \\
\hline 2834 & 0.991 & 0.991 & 1.011 & 0.963 & 0.011 & 0.280 & 0.212 & 0.611 & 0.021 & 0.164 \\
\hline 2836 & 0.977 & 0.979 & 0.988 & 0.960 & 0.007 & 0.298 & 0.240 & 0.557 & 0.101 & 0.146 \\
\hline 2837 & 0.992 & 1.001 & 1.075 & 0.886 & 0.041 & 0.301 & 0.233 & 0.564 & 0.027 & 0.144 \\
\hline 2838 & 0.980 & 0.984 & 1.009 & 0.946 & 0.015 & 0.417 & 0.401 & 0.580 & 0.256 & 0.080 \\
\hline 2845 & 1.000 & 1.004 & 1.055 & 0.931 & 0.033 & 0.452 & 0.461 & 0.706 & 0.087 & 0.175 \\
\hline 2847 & 0.981 & 0.982 & 1.027 & 0.933 & 0.024 & 0.365 & 0.307 & 0.706 & 0.133 & 0.164 \\
\hline 2849 & 0.988 & 0.990 & 1.054 & 0.946 & 0.024 & 0.386 & 0.356 & 0.643 & 0.114 & 0.166 \\
\hline
\end{tabular}

The table lists the descriptive statistics for important variables used in the empirical analysis, covering a sample of 10 banks from 2000 to 2009. Tobin's q is calculated as the sum of the market value of common equity, plus the book value of preferred shares, plus the book value of total debt, divided by the book value of total assets. Herfindal $\mathrm{H}=1-\left[(\text { interest revenue/total revenue })^{2}+(\right.$ handling fee and handling charge commission revenue/total revenue $)^{2}+($ financial transaction revenue/total revenue $\left.)^{2}+(\text { other revenue/total revenue })^{2}\right]$.

As Table 1 shows, the corporate value indicator (Tobin's q) and diversification indicator (Herfindal $\mathrm{H}$ ) have no apparent relationship in the sample, the banks' $\mathrm{Q}$ and $H$ values have no relevant relationships in terms of rising or falling with changes in the sample, and the average value and variance are in the similar situation.

\subsection{Optimum Diversification}

This section describes the effect of diversification on bank value in order to test whether an optimal level of diversification exists that can maximize the value of the bank. The following section discusses the selection of the proxy indicators for bank value and diversification, and the testing model of the optimal diversification.

\subsubsection{Value Index Tobin's Q}


We use Tobin's q as a measure of bank valuation. Tobin's q is calculated as the sum of the market value of common equity, plus the book value of preferred shares, plus the book value of total debt, divided by the book value of total assets. Lang and Stulz (1994) employed Tobin's $\mathrm{q}$ to observe the relationship between corporate diversification and performance, arguing that Tobin's q contains the capitalized value of diversification. Under the hypothesis of an efficient market and market value as the unbiased estimated value of the current cash flow of the company, Tobin's q can measure the contributions of the intangible assets of the company to market value. Hence, management activities (e.g., diversification) can increase or decrease corporate value through the impact of intangible assets. When the company's investment portfolio changes, its Tobin's q will also change.

Most of the recent studies related to diversification use Tobin's $q$ and relevant indicators to measure the relationship between the value of financial institutions and diversification (Elsas et al., 2010; Laeven and Levine, 2007; Stiroh and Rumble, 2006; Whited, 2001). Most of the modifications related to Tobin's q are based on changes in business operational activities after the establishment of financial holding companies. However, sample banks selected for the present study do not include financial holding companies, so this study uses Tobin's q to measure changes in corporate value in order to explore the impact of diversification on corporate value.

\subsubsection{Diversification Index}

When the diversification indicator is calculated from the perspective of the bank's profitability, the profit-making activities are divided into interest-rate-related activities and non-interest-rate-related activities. Stiroh and Rumble (2006) studied the impact of diversification on the performance of American financial holding companies and found that diversification facilitates the revenue from interest-rate-related activities and that diversification is detrimental to non-interest-rate-related activities. As the non-interest-rate-related activities have higher fluctuations and the profit-making capabilities are not necessarily higher than the interest rate-related activities, asset diversification in non-interest-rate-related activities lowers the performance of the financial holding companies. The establishment of diversification indicators by Stiroh and Rumble is illustrated as follows:

$$
D I V=1-\left(S H_{N E T}^{2}+S H_{N O N}^{2}\right)
$$

$S H_{N E T}^{2}$ : is the share of net operating revenue from net interest sources 
$S H_{N O N}^{2}$ : is the share of net operating revenue from non-interest sources

Laeven and Levine (2007) studied the diversification effect of financial integration on corporate market value by categorizing the operational activities that affect diversification into loan-related activities and non loan-related activities. Their findings suggested that the economies of scope of business diversification after financial integration do not generate diversification premiums. The diversification indicator is set as illustrated below:

$$
\text { Diversification }(L L)=1-\left|\frac{\text { net interest income- other operating income }}{\text { total operating income }}\right|
$$

Elsas et al. (2010) studied how diversification affected the value of bank during the 1996-2008 in nine countries. They classified the bank's non-interest-related activities into net commission revenue, net trading revenue, and all other net revenue. The set diversification indicator is illustrated below:

$$
D I V=1-\left[\left(\frac{I N T}{T O R}\right)^{2}+\left(\frac{C O M}{T O R}\right)^{2}+\left(\frac{T R A D}{T O R}\right)^{2}+\left(\frac{O T H}{T O R}\right)^{2}\right]
$$

INT: gross interest revenue

COM: net commission revenue

TRAD: net trading revenue

OTH: all other net revenue

TOR: total operating revenue, which is equal to the sum of the absolute values of INT, COM, TRAD and OTH.

Referring to the diversification indicators proposed by Elsas et al.(2010), this study, in accordance with the items on the balance sheet of Taiwan's banking industry, categorizes the revenue sources of the banks into four types in order to calculate the banks' diversification indicator:

$\mathrm{H}=1-\left[(\text { interest revenue/total revenue })^{2}\right.$

$+(\text { handling fee and handling charge commission revenue/total revenue })^{2}$

$+(\text { financial transaction revenue/total revenue })^{2}$

$\left.+(\text { other revenue/total revenue })^{2}\right]$

\subsubsection{Regression Model}

This section tests the impact of diversification on corporate value in order to verify 
the existence of an optimal level of diversification in the sample banks in Taiwan. Tobin's q is used as the measurement indicator of the value of the bank, and $\mathrm{H}$ is used as the diversification indicator of the bank's revenue to establish the regression model:

$\mathrm{Q}=\mathrm{c}+\mathrm{a}_{1} \mathrm{H}+\mathrm{a}_{2} \mathrm{H}^{2}$

$\mathrm{Q}$ : Tobin $\mathrm{Q}=(\mathrm{M} / \mathrm{B})=($ Market Value/Book Value $)$

$\mathrm{H}$ : the degree of diversification,

c: the effects of other influencing factors

If the operational purpose of the bank is to maximize its value (Max Q), and there is an optimal level of diversification $\mathrm{H}$, then $\mathrm{H}$ should satisfy the following two conditions:

Condition I,

$\frac{d^{2} Q}{d H^{2}}<0$, Second-order condition, namely, $\mathrm{H}^{2}$ regression coefficient $\mathrm{a}_{2}<0$, representing that the existence of diversification has maximized corporate value.

Condition II,

The optimum diversification: $H^{*}=\frac{a_{1}}{-2 a_{2}}>0$; hence, the regression coefficient is $\mathrm{a}_{1}>0$.

\subsubsection{Test Results}

If the effects of reducing individual risk through the bank's diversification are greater than the effects of increasing system risk, there should be an optimal level of diversification to maximize the value of the bank. This paper uses the corporate value $\mathrm{Q}$ of Taiwan's sample banks to conduct a regression estimation of the diversification variables $\mathrm{H}$ and $\mathrm{H}^{2}$, leading to the results shown in Table 2.

Table 2 Regression Results for Optimal Diversification

\begin{tabular}{|c|c|c|c|c|c|c|c|}
\hline Bank & $\mathbf{C}$ & & $\mathbf{H}$ & & $\mathbf{H}^{2}$ & & Adj.- $R^{2}$ \\
\hline & Coeff. & p-value & Coeff. & p-value & Coeff. & p-value & \\
\hline 2801 & 0.9616 & $0.0000^{* * *}$ & 0.2432 & $0.0000^{* * *}$ & -0.3002 & $0.0000^{* * *}$ & 0.3502 \\
\hline 2809 & 0.9425 & $0.0000^{* * *}$ & 0.3667 & $0.0000^{* * *}$ & -0.5502 & $0.0000^{* * *}$ & 0.4077 \\
\hline 2812 & 0.9491 & $0.0000^{* * *}$ & 0.2291 & $0.0004^{* * *}$ & -0.2885 & $0.0015^{* * *}$ & 0.1144 \\
\hline 2834 & 0.9778 & $0.0000^{* * *}$ & 0.0658 & $0.0033^{* * *}$ & -0.0504 & 0.1433 & 0.2730 \\
\hline 2836 & 0.9626 & $0.0000^{* * *}$ & 0.1446 & $0.0000^{* * *}$ & -0.2004 & $0.0000^{* * *}$ & 0.1244 \\
\hline 2837 & 0.9031 & $0.0000^{* * *}$ & 0.7495 & $0.0000^{* * *}$ & -1.2301 & $0.0000^{* * *}$ & 0.2699 \\
\hline 2838 & 0.8376 & $0.0000^{* * *}$ & 0.6151 & $0.0002^{* * *}$ & -0.6340 & $0.0008^{* * *}$ & 0.2231 \\
\hline
\end{tabular}




$\begin{array}{llllllll}\mathbf{2 8 4 5} & 0.8404 & 0.0000^{* * *} & 0.7383 & 0.0000^{* * *} & -0.7422 & 0.0000^{* * *} & 0.6366 \\ \mathbf{2 8 4 7} & 0.9017 & 0.0000^{* * *} & 0.3378 & 0.0000^{* * *} & -0.2779 & 0.0001^{* * *} & 0.5297 \\ \mathbf{2 8 4 9} & 0.9003 & 0.0000^{* * *} & 0.4031 & 0.0000^{* * *} & -0.3851 & 0.0000^{* * *} & 0.6197\end{array}$

Tobin's q is calculated as the sum of the market value of common equity, plus the book value of preferred shares, plus the book value of total debt, divided by the book value of total assets. Herfindal $\mathrm{H}=1$-[(interest revenue/total revenue $)^{2}+($ handling fee and handling charge commission revenue/total revenue $\left.)^{2}+(\text { financial transaction revenue/total revenue })^{2}+(\text { other revenue/total revenue })^{2}\right]$.

* significant at the $10 \%$ level.

** significant at the $5 \%$ level.

*** significant at the $1 \%$ level.

As Table 2 shows, the regression coefficients of the first-order variable $\mathrm{H}$ of diversification against the bank value variable $Q$ at the $1 \%$ significance level is positive, indicating that increasing diversification leads to rising corporate value. The regression coefficients of the second-order variable $\mathrm{H}^{2}$ of diversification at the $1 \%$ significance level are mostly positive except for one sample, indicating that diversification can maximize corporate value. Hence, Taiwan's banking sample suggests that diversification's positive effects on bank value (reducing individual risk) are greater than the negative effects (increasing system risk).

Regarding the impact of economic conditions on the optimal level of diversification, this study organizes the probability of corporate value to be lower than liability value in conducting the sensitivity analysis and finds no significant results. It is not easy to estimate accurately the loss probability $q$ and the observation value $s$ of the highest possible value of the bank's investment assets. Therefore, this question is expected to be explored in future studies. Among the sample banks in Taiwan, the Taichung Commercial Bank (2812) and the Kaohsiung Bank (2836) have higher risks (risk incidents had taken place) than other banks. The probability of liquidation conditions of the two samples, the $\mathrm{d} / \mathrm{s}$ values, are more likely to exceed the threshold, so an optimal level of diversification is less likely. However, the regression fitness of the two samples is relatively poor (relatively smaller modified $\mathrm{R}^{2}$ ), and the representativeness is weak. The probability of the liquidation condition indicator, the $\mathrm{d} / \mathrm{s}$ value of other sample banks, is more likely to exceed the threshold; hence, the possibility that there is an optimal level of diversification in Taiwan's banking industry is relatively high.

\section{Conclusions}

There are many explanations for the benefits of diversification in financial institutions. Most of the early literature contended that diversification could improve corporate value. From the risk perspective, the most widely accepted explanation is that it can lower the average risk of the portfolio. However, using the viewpoint of risk 
contagion, Wagner (2010) discussed the impact of diversification on corporate value and found that when diversification increases similarly among financial institutions, chances of system risk increase, thereby reducing corporate value. As a result, full diversification may not be the optimum solution, and the optimal level of diversification may be lower than expected. Wagner (2010) confirmed the adverse effects of diversification on risk and posed other problems: does an optimal level of diversification exist? If so, what factors influence it? Hence, based on the model proposed by Wagner, this study attempts to determine whether there is an optimal level of diversification to maximize corporate value.

For financial institutions, diversification may reduce individual risk and improve corporate value, as well as increasing system risk and lowering corporate value. Hence, if the integration results of the two are beneficial to the corporation, there is an optimal level of diversification to maximize corporate value. This study finds that diversification's impact on corporate value is related to the business cycle such that, when the economy is good, there is an optimal level of diversification to maximize banks' value, and when the economy is bad, diversification will hurt banks' value. Moreover, the optimal level of diversification and the loss rate are in an inversely changing relationship. These results suggest that the integration effect of diversification in good economies are beneficial, and investment should increase, while the integration effects of diversification are negative in poor economies, and investment should be reduced.

Most of the recent empirical studies on the impact of diversification on the value of financial institutions begin from the perspective of financial integration to test whether corporate value falls after financial integration. Such limitations are not generalized. Hence, with Taiwan's banks as an example, this study tests the impact of diversification on the banks' value and finds that, in the case of the sample banks, there is an optimal level of diversification to maximize corporate value. This finding suggests that Taiwan's economic conditions still benefit the diversification of the banking industry. However, this study does not verify the indicators of conditions leading to probability of liquidation or loss rate, which may be considerations for future study.

\section{REFERENCES}

Acharya, V., 2001. A Theory of Systemic Risk and Design of Prudential Bank Regulation, Mimeo, London Business School.

Acharya, V. and Yorulmazer, T., 2005. Limited Liability and Bank Herding, Mimeo, London Business School. 
Acharya, V. and Yorulmazer, T., 2007. Too Many to Fail - an Analysis of Time Inconsistency in Bank Closure Policies, Journal of Financial Intermediation, 16 (1), 1-31.

Acharya, V. and Yorulmazer, T., 2008. Cash-in-the-Market Pricing and Optimal Resolution of Bank Failures, Review of Financial Studies, 21(6), 2705-2742.

Allen, F. and Carletti, E., 2006. Credit risk transfer and contagion, Journal of Monetary Economics, 53(1), 89-111.

Allen, F. and Gale, D., 2005. Systemic risk and regulation. In: Carey, M., Stulz, R. (Eds.), The Risks of Financial Institutions, Chicago University Press.

Amihud, Y. and Lev, B., 1981. Risk reduction as managerial motive for conglomerate mergers, Bell Journal of Economics, 12(2), 605- 617.

Bhide, A., 1990. Reversing corporate diversification, Journal of Applied Corporate Finance, 3(2), 70-81.

Bodnar, G. M., Tang, C. and Weintrop, J., 1999. Both Sides of Corporate Diversification: The Value Impacts of Geographic and Industrial Diversification, Unpublished manuscript, Paul H. Nitze School of Advanced International Studies, Johns Hopkins University (December).

Chandler, A.D., 1977. The Visible Hand: The Managerial Revolution in American Business, Belknap Press, Cambridge, MA.

Elsas, R., Hackethaland, A. and Holzhäuse, M., 2010. The anatomy of bank diversification, Journal of Banking \& Finance, 34(6), 1274-1287.

Ghemawat, P., 2000. Competition and Business Strategy in Historical Perspective, Unpublished manuscript, Harvard Business School (April).

Goldstein, I. and Pauzner, A., 2004. Contagion of self-fulfilling financial crises due to diversification of investment portfolios, Journal of Economic Theory, 119(1), 151-183.

Goold, M. and Luchs, K., 1993. Why diversify? Four decades of management thinking, Academy of Management Journal, 7(3), 7 - 25.

Hadlock, C., Ryngaert, M. and Thomas, S., 2001. Corporate structure and equity offerings: are there benefits to diversification? Journal of Business, 74(4), 613-35.

Harris, M., Kriebel, C. and Raviv, A., 1992. Asymmetric information, incentives, and intrafirm resource allocation, Management Science, 28(6), 604-620.

Jensen, M. C., 1986. Agency costs of free cash flow, corporate finance and takeovers, American Economic Review, 76(2), 323- 329.

Jensen, M. and Murphy, K. J., 1990. Performance pay and top management incentives, Journal of Political Economy, 98(2), 225-264.

Khanna, N. and Palepu, K., 1999. Corporate Scope and Institutional Context: An 
Empirical Analysis of Diversified Indian Business Groups, Unpublished manuscript, Harvard University.

Laeven, L. and Levine, R. 2007. Is there a diversification discount in financial conglomerates? Journal of Financial Economics, 85(2), 331-367

Laeven, L. and Harry, H., 2009. Accounting Discretion of Banks During a Financial Crisis, IMF Working Papers, 1-41.

Lamont, O., 1997. Cashflow and investment: Evidence from internal capital markets, Journal of Finance, 52(1), 83-109.

Lang, L. H. P. and Stulz, R. M., 1994. Tobin's q, Corporate Diversification, and Firm Performance, The Journal of Political Economy, 102(6), 1248-1280.

Lewellen, W., 1971. A pure financial rationale for the conglomerate merger, Journal of Finance, 26(2), 521-537.

Meyer, M., Milgrom, P. and Roberts, J., 1992. Organizational prospects, influence costs, and ownership changes, Journal of Economics and Management Strategy, $1(1), 9-35$.

Montgomery, C.A., 1994. Corporate diversification, Journal of Economic Perspectives, 8(3), 163- 178.

Penrose, E.T., 1959. The Theory of the Growth of the Firm, Wiley, New York.

Rajan, R., Servaes, H. and Zingales, L., 2000. The cost of diversity: The diversification discount and inefficient investment, Journal of Finance, 55(1), $35-80$.

Scharfstein, D. and Stein, J.C., 2000a. The Dark Side Of Internal Capital Markets: Divisional Rent-Seeking And Inefficient Investment, Journal of Finance, 55(6), 2537-2564.

Scharfstein, D. and Stein, J.C., 2000b. Herd behavior and investment: Reply, American Economic Review, 80(3), 465-479.

Shleifer, A. and Vishny, R., 1990. Managerial entrenchment, the case of manager specific investments, Journal of Financial Economics, 25(1), 123- 139.

Shleifer, A. and Vishny, R., 1991. The takeover wave of the 1980s, Journal of Applied Corporate Finance, 4(3), 49- 56.

Stein, J.C., 1997. Internal capital markets and the competition for corporate resources, Journal of Finance, 52(1), $111-133$.

Stiroh, K. J. and Rumble, A., 2006.The dark side of diversification: The case of US financial holding companies, Journal of Banking and Finance, 30(8), 2131-2161.

Teece, D.J., 1982. Towards an economic theory of the multiproduct firm, Journal of Economic Behaviour and Organization, 3(1), 39-63.

Villalonga, B., 2000. An Empirical Analysis of Diversification Motives, Unpublished manuscript, Anderson Graduate School of Management, University of California, 
Los Angeles.

Wagner, W., 2010. Diversification at financial institutions and systemic crises, Journal of Financial Intermediation, 19(3), 373-386.

Wernerfelt, B. and Montgomery, C.A., 1988. Tobin's q and the importance of focus in firm performance, American Economic Review, 78(1), 246-250.

Whited, T.S., 2001. Is It Inefficient Investment that Causes the Diversification Discount, Journal of Finance, 56(5), 1667-1691.

Williamson, O., 1975. Markets and Hierarchies: Analysis and Antitrust Implications, Collier Macmillian Publishers, New York.

\section{Appendix A.}

Substituting $d$ for $v_{1}$ in equation (2) yields

$$
L_{1}: y=\frac{d}{r_{1}}-\frac{\left(1-r_{1}\right)}{r_{1}} x
$$

In fig. 1 , the dotted line depicts $L_{1}$ when $r_{1}=1 / 2$. As $r_{1}$ approaches zero, $L_{1}$ closes to the dashed line, $x=d$. Since $r_{1}$ is restricted to between 0 and $1 / 2, L_{1}$ can lie only in areas I or II. First, consider that $r_{1}$ is chosen such that $L_{1}$ lies on area I. In this situation, as shown in Fig 2, $\left.A=\left\{(x, y) \mid v_{1}(r) \leq d, v_{2}(r)>d\right)\right\}$, while $B \cup C \cup D=P\left(v_{1}(r) \leq d, v_{2}(r) \leq d\right)$. Hence, we have

$$
\begin{aligned}
& c\left(P\left(v_{1}(r) \leq d, v_{2}(r)>d\right)+q P\left(v_{1}(r) \leq d, v_{2}(r) \leq d\right)\right) \\
& =c(P((x, y) \in A)+q P((x, y) \in B \cup C \cup D)) \\
& =c(P((x, y) \in A \cup B \cup C \cup D)+(q-1) P((x, y) \in B \cup C \cup D)) \\
& =\frac{c}{s^{2}}\left(\frac{d^{2}}{2 r(1-r)}+(q-1) \frac{d^{2}}{1-r}\right)
\end{aligned}
$$

Thus, the optimal degree of diversification solves

$$
\left(\frac{d^{2}}{2 r(1-r)}+(q-1) \frac{d^{2}}{1-r}\right)^{\prime}=0
$$

Solving (a2) yields

$$
r=\frac{1}{1+\sqrt{2 q-1}} .
$$

Since in region I, $r$ is restricted to be between $d / s$ and $1 / 2$, the optimal diversification in region $I$ is

$$
r_{\mathrm{I}}^{*}=\operatorname{Max}\left\{\frac{1}{1+\sqrt{2 q-1}}, \frac{d}{s}\right\} .
$$


Similarly, suppose that $r_{1}$ is chosen such that $L_{1}$ lies in area II. As shown in Fig 3, we have

$$
\begin{aligned}
& c\left(P\left(v_{1}(r) \leq d, v_{2}(r)>d\right)+q P\left(v_{1}(r) \leq d, v_{2}(r) \leq d\right)\right) \\
& =c(P((x, y) \in E)+q P((x, y) \in F \cup G \cup H)) \\
& =c(P((x, y) \in E \cup F \cup G \cup H)+(q-1) P((x, y) \in F \cup G \cup H)) \\
& =\frac{c}{s^{2}}\left(\frac{r s^{2}}{2(r-1)}+\frac{d s}{1-r}+(q-1) \frac{d^{2}}{1-r}\right)
\end{aligned}
$$

Denoting $f(r)=\frac{r s^{2}}{2(r-1)}+\frac{d s}{1-r}+(q-1) \frac{d^{2}}{1-r}$, we have

$$
f^{\prime}(r)=\frac{1}{(r-1)^{2}}\left(\frac{-s^{2}}{2}+d s+(q-1) d^{2}\right) \text {. }
$$

Analyzing (a5), we find that $f(r)$ increases in $r$ when $\frac{d}{s}>\frac{1}{1+\sqrt{2 q-1}}$

and decreases when $\frac{d}{s} \leq \frac{1}{1+\sqrt{2 q-1}}$. Therefore, the optimal diversification in region II is

$$
r_{\mathrm{II}}^{*}=\left\{\begin{array}{c}
0, \text { if } \frac{d}{s}>\frac{1}{1+\sqrt{2 q-1}} \\
d / s, \text { if } \frac{d}{s} \leq \frac{1}{1+\sqrt{2 q-1}}
\end{array}\right.
$$

Combining (a3) and (a6), the optimal degree of diversification is given by $r^{*}=\frac{1}{1+\sqrt{2 q-1}}$ when $\frac{d}{s} \leq \frac{1}{1+\sqrt{2 q-1}}$, and $r^{*}=0$ when $\frac{d}{s}>\frac{1}{1+\sqrt{2 q-1}}$.

\section{Appendix B.}

Bank 1's maximization problem is equivalent to

$$
\operatorname{Min}_{\mathrm{r}_{1}} c\left(P\left(v_{1}\left(r_{1}\right) \leq d, v_{2}\left(r_{2}\right)>d\right)+q P\left(v_{1}\left(r_{1}\right) \leq d, v_{2}\left(r_{2}\right) \leq d\right)\right)
$$

Similar to the proof shown in Appendix A, we first consider that $r_{1}$ is chosen such that $L_{1}$ is restricted to area $\mathrm{I}$. In this situation,

$$
\begin{aligned}
& P\left(v_{1}\left(r_{1}\right) \leq d, v_{2}\left(r_{2}\right)>d\right)+q P\left(v_{1}\left(r_{1}\right) \leq d, v_{2}\left(r_{2}\right) \leq d\right) \\
& =\frac{d^{2}}{2 r_{1}\left(1-r_{1}\right) s^{2}}+\frac{(q-1)}{s^{2}}\left(\frac{1}{2} \frac{d^{2}}{1-r_{1}}+\frac{d^{2}}{2}+P\left((x, y) \in B \mid r_{2}\right)\right) .
\end{aligned}
$$


Therefore, the optimal degree of diversification in region I solves

$$
\frac{\partial}{\partial r_{1}}\left(\frac{d^{2}}{2 r_{1}\left(1-r_{1}\right) s^{2}}+\frac{(q-1)}{s^{2}}\left(\frac{d^{2}}{2\left(1-r_{1}\right)}+\frac{d^{2}}{2}+P\left((x, y) \in B \mid r_{2}\right)\right)\right)=0
$$

Solving (a9) yields the optimal diversification in region I:

$$
r_{\mathrm{I}}^{+}=\operatorname{Max}\left\{\frac{1}{1+\sqrt{q}}, \frac{d}{s}\right\}
$$

Now suppose that $L_{1}$ is restricted to region II. In this situation,

$$
\begin{aligned}
& P\left(v_{1}\left(r_{1}\right) \leq d, v_{2}\left(r_{2}\right)>d\right)+q P\left(v_{1}\left(r_{1}\right) \leq d, v_{2}\left(r_{2}\right) \leq d\right) \\
& =\frac{r_{1}}{2\left(r_{1}-1\right)}+\frac{d}{\left(1-r_{1}\right) s}+\frac{(q-1)}{s^{2}}\left(\frac{d^{2}}{2\left(1-r_{1}\right)}+\frac{d^{2}}{2}+P\left((x, y) \in B \mid r_{2}\right)\right) .
\end{aligned}
$$

Denoting $g\left(r_{1}, r_{2}\right)=\frac{r_{1}}{2\left(r_{1}-1\right)}+\frac{d}{\left(1-r_{1}\right) s}+\frac{(q-1)}{s^{2}}\left(\frac{d^{2}}{2\left(1-r_{1}\right)}+\frac{d^{2}}{2}+P\left((x, y) \in B \mid r_{2}\right)\right) \quad, \quad$ we have

$$
\frac{\partial g\left(r_{1}, r_{2}\right)}{\partial r_{1}}=\frac{1}{s^{2}\left(r_{1}-1\right)^{2}}\left(\frac{-s^{2}}{2}+d s+(q-1) \frac{d^{2}}{2}\right) .
$$

Analyzing (a12), we find that $g\left(r_{1}, r_{2}\right)$ increases in $r_{1}$ when $\frac{d}{s}>\frac{1}{1+\sqrt{q}}$ and decreases when $\frac{d}{s} \leq \frac{1}{1+\sqrt{q}}$. Therefore, the optimal diversification in region II is

$$
r_{\mathrm{II}}^{*}=\left\{\begin{array}{c}
0, \text { if } \frac{d}{s}>\frac{1}{1+\sqrt{q}} \\
d / s, \text { if } \frac{d}{s} \leq \frac{1}{1+\sqrt{q}}
\end{array}\right.
$$

Combining (a10) and (a13), the equilibrium degree of diversification in the banking sector is given by $r^{E}=\frac{1}{1+\sqrt{q}}$ when $\frac{d}{s} \leq \frac{1}{1+\sqrt{q}}$, and $r^{E}=0$ when $\frac{d}{s}>\frac{1}{1+\sqrt{q}}$. 


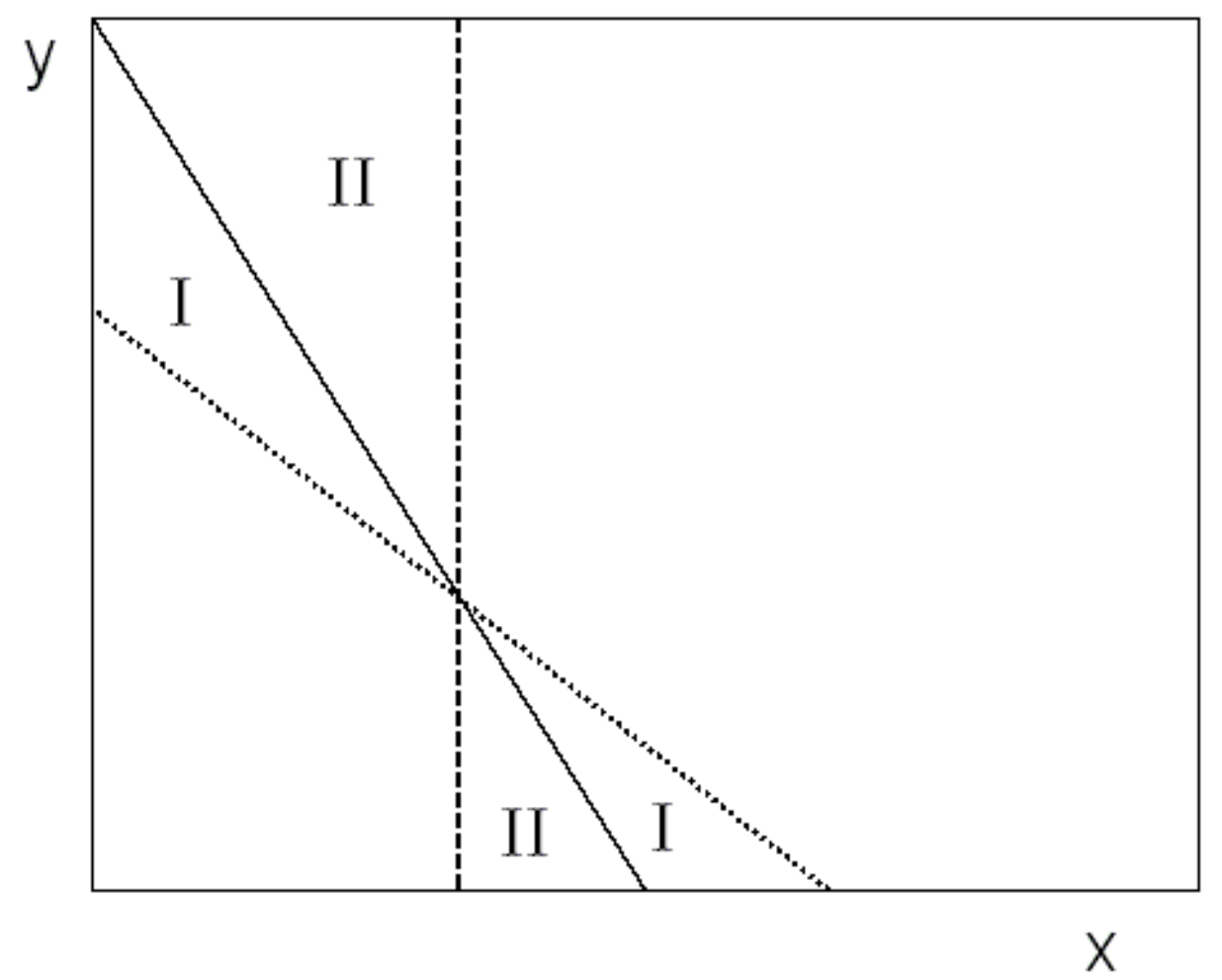

Fig. 1

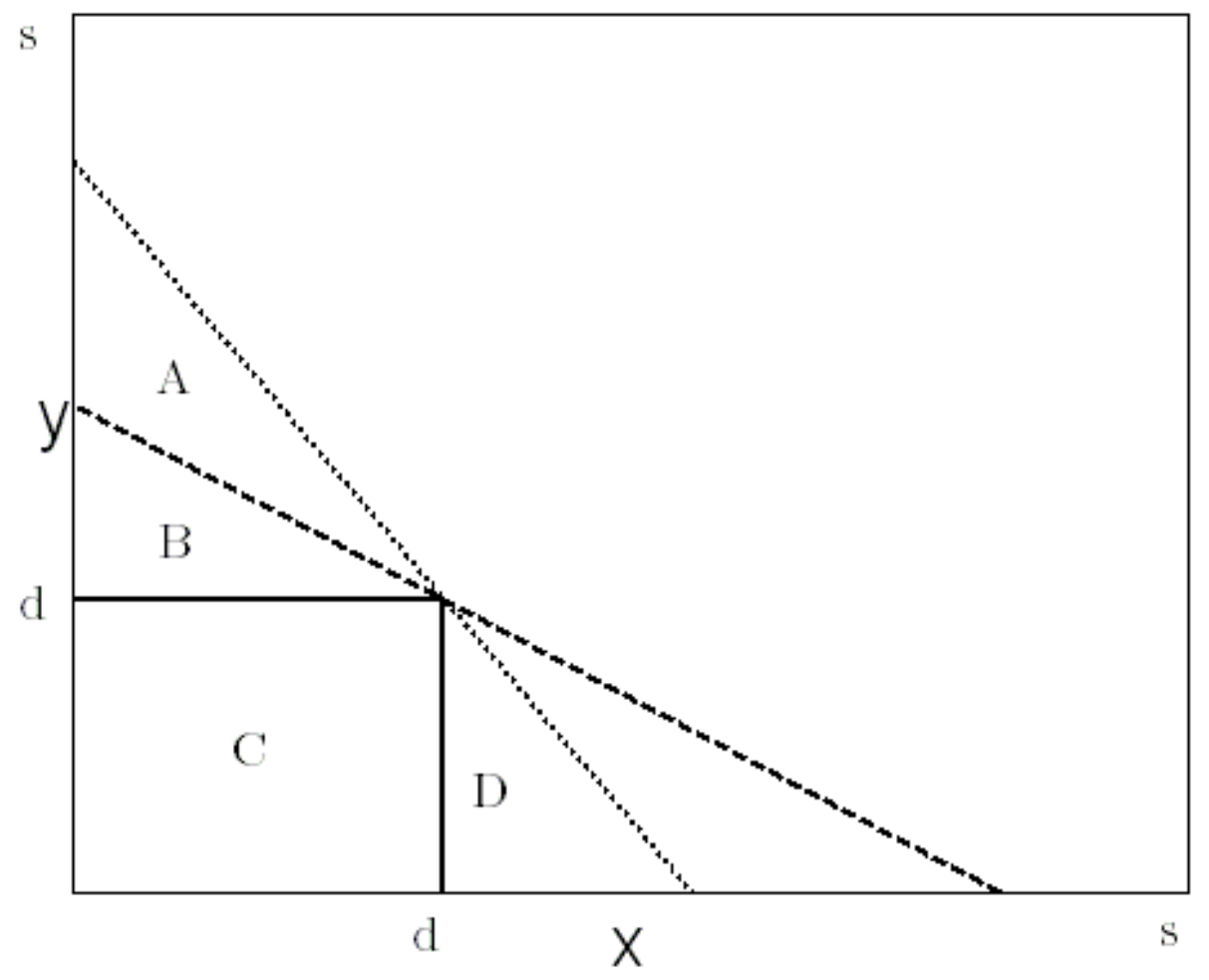


Fig. 2

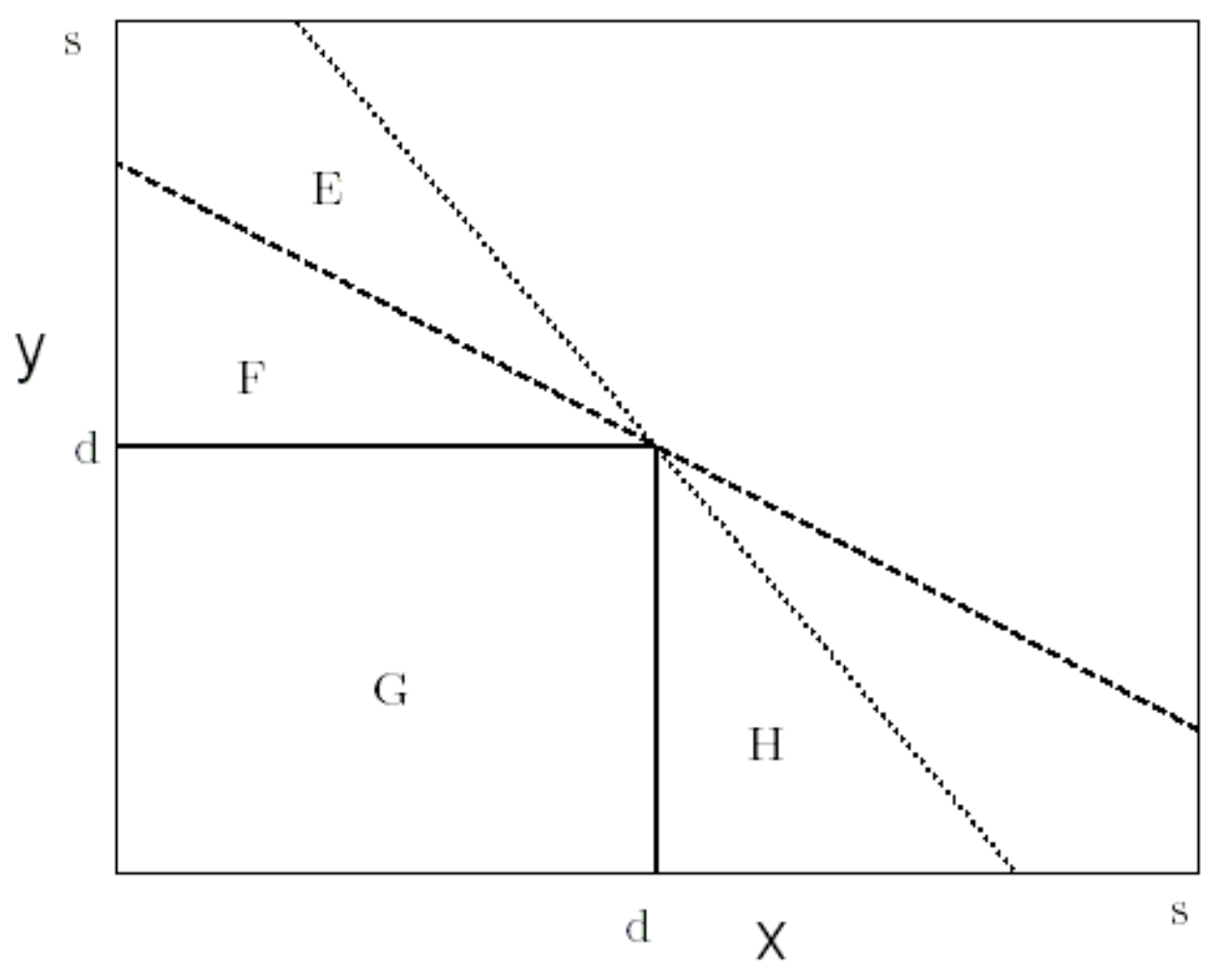

Fig. 3 


\section{Appendix C.}

Table 3 The sample banks of Taiwan

\begin{tabular}{ll}
\hline Symbol & Company Name \\
\hline 2801 & Chang Hwa Commercial Bank \\
2809 & Kings Town Commercial Bank \\
2812 & Taichung Commercial bank \\
2834 & Taiwan Business Bank \\
2836 & Kaohsiung Bank \\
2837 & Cosmos Commercial Bank \\
2838 & Union Commercial Bank \\
2845 & Far Eastern International Commercial Bank \\
2847 & Ta Chong Commercial Bank \\
2849 & EnTie Commercial Bank \\
\hline
\end{tabular}

